\title{
Socio-Economic Impact Assessment of Proposed Road Project Kimerdingay-atekna-Meketwuha Road Project, Amhara Region, Ethiopia
}

\author{
Getahun Abebe Tewlate (MSC) \\ Socio-Economist, Amhara National Regional State Road and Building Design Construction Supervision Works \\ Enterprise
}

\begin{abstract}
The Kimerdingay-Atekna-Meketwuha proposed road project is administratively located in Amhara National Regional State, South Gondar Administrative Zone between Guna Bigimeder and Meketwuha woredas .The overall positive socioeconomic impacts of the proposed road project include availability of all-weather reliable roads, reduced transportation costs, increased access to market places for local produces, access to new employment centers, better access to social service centers like health institutions, and strengthening of local economy are felt during the operation phases of the project road. However, the direct and adverse impacts are increased traffic accidents, pollution due to increased vehicle exhaust gases and transportation of hazardous material in transit, noise and road side litter, displacement of people, damages to properties and crops, reduction of size of farmland, interruption of social services like water supply, electricity and telecommunication services, expansion of HIV/AIDS and other STDs, drug abuse, commercial sex work, child labor, theft, exhaustion of natural resources, price escalation at local level etc.Mixed methods of data collection both primary and secondary data source were used. Field observation, photo, Goagle earth, transect walk, published and unpublished woredas sectoral report, discussion with the respective project woredas cabinet , and formal and informal public discussion along the project kebles. The road project directly connect Guna Bigmider with Meketwuha woredas and connect Kimirdngay_Wukiro_Amijaya_Atikna_Giday_Aiyada_Aija_Zikilmoka_Aidiya_Aighisa kebles. The total project population along the project kebles are male $=42,779$ female $=40,039$ Along the proposed road project kebles there are three primary, twenty three primary full cycle, one secondary and one secondary and preparatory schools. And also there are ten heath post, four health center and nine animal health post.
\end{abstract}

Keywords: proposed road, project, socioeconomic impact, adverse, positive, mitigation measure

DOI: $10.7176 / \mathrm{CER} / 11-3-04$

Publication date: April $30^{\text {th }} 2019$

\section{Introduction}

The implementation of road infrastructure consumes resources and occupies wider land surfaces. It requires large plots of land all along the stretch and beyond, large volume of material has to be transported from its original site and numbers of equipment and man power have to be mobilized and deployed in the area. All of these resources mobilization can bring in changes to the socioeconomic environment of the project area and its environs in one way or another.

The overall positive socioeconomic impacts of the proposed road project include availability of all-weather reliable roads, reduced transportation costs, increased access to market places for local produces, access to new employment centers, better access to social service centers like health institutions, and strengthening of local economy are felt during the operation phases of the project road. However, the direct and adverse impacts are increased traffic accidents, pollution due to increased vehicle exhaust gases and transportation of hazardous material in transit, noise and road side litter, displacement of people, damages to properties and crops, interruption of social services like water supply, electricity and telecommunication services, expansion of HIV/AIDS and other STDs, drug abuse, commercial sex work, child labor, theft, exhaustion of natural resources, price escalation at local level etc.

Yet, some of the benefits/adverse impacts are quantitatively measured, while others are qualitatively measured. It is used here to combine qualitative and quantitative adverse impacts are increased traffic accidents, pollution due to increased vehicle exhaust gases and transportation of hazardous material in transit, noise and road side litter, displacement of people, damages to properties and crops, interruption of social services like water supply, electricity and telecommunication services, expansion of HIV/AIDS and other STDs, drug abuse, commercial sex work, child labor, theft, exhaustion of natural resources, price escalation at local level etc. data into a single framework to select social, economic and environmental viable.

The Kimerdingay-Atekna-Meketwuha road project is administratively located in Amhara National Regional State, South Gondar Administrative Zone between Guna Bigimeder and Meketwuha woredas.

It links Guna Bigimeder woreda with Meketwuha woreda and directly to zonal town of Debrtabor.

The starting point of the road project Guna Bigimeder woreda administrative center at Kimiridngay urban 00 
k.m at approximately $1305756.474 \mathrm{~N}, 414924.165 \mathrm{E}$ and $2964.000 \mathrm{~m}$ Elv. And ends Mektewuha woreda approximately $1333339.350 \mathrm{~N}, 422200.218 \mathrm{E}$ and $2064.919 \mathrm{~m}$ Elv.

The starting point of the project road is $30 \mathrm{~km}$ from the zonal town Debretabor, $132 \mathrm{~km}$ from Bahir Dar, the capital city of the Amhara national region state and $690 \mathrm{k} . \mathrm{m}$ from Addis Ababa capital city of the country on the highway of Bahirdar-Woreta-Woldiya asphalt road. (woreda government communication office).

\section{General Objective}

The general objective of the socioeconomic impact assessment of the Kimerdingay-Atekna-Meketwuha proposed road project to assess the overall positive and adverse impact of the project during construction and after and the possible mitigation measure.

\section{Specific Objective}

To assesses the positive impact of the road project during the construction and after

To assesses the adverse impact of the road project during and after construction

To assess the possible mitigation measure of the adverse impact road project

\section{Methods of the Study}

Mixed methods of data collection both primary and secondary data source were used. Field observation, photo, Goagle earth, transect walk, published and unpublished woredas sectoral report, discussion with the respective project woredas cabinet , and formal and informal public discussion along the project kebles.

\section{Data source}

Primary data source as field observation, photo, transect walk, focus group discussion, formal and informal meeting, public discussion and others.

Secondary data source as review of related literatures such as published and unpublished project woreda reports, past studies, policy documents, reports of programs and road infrastructures related projects in the study district (GO, NGOs, Bilateral and Multilateral agencies). Google earth, pamphlet

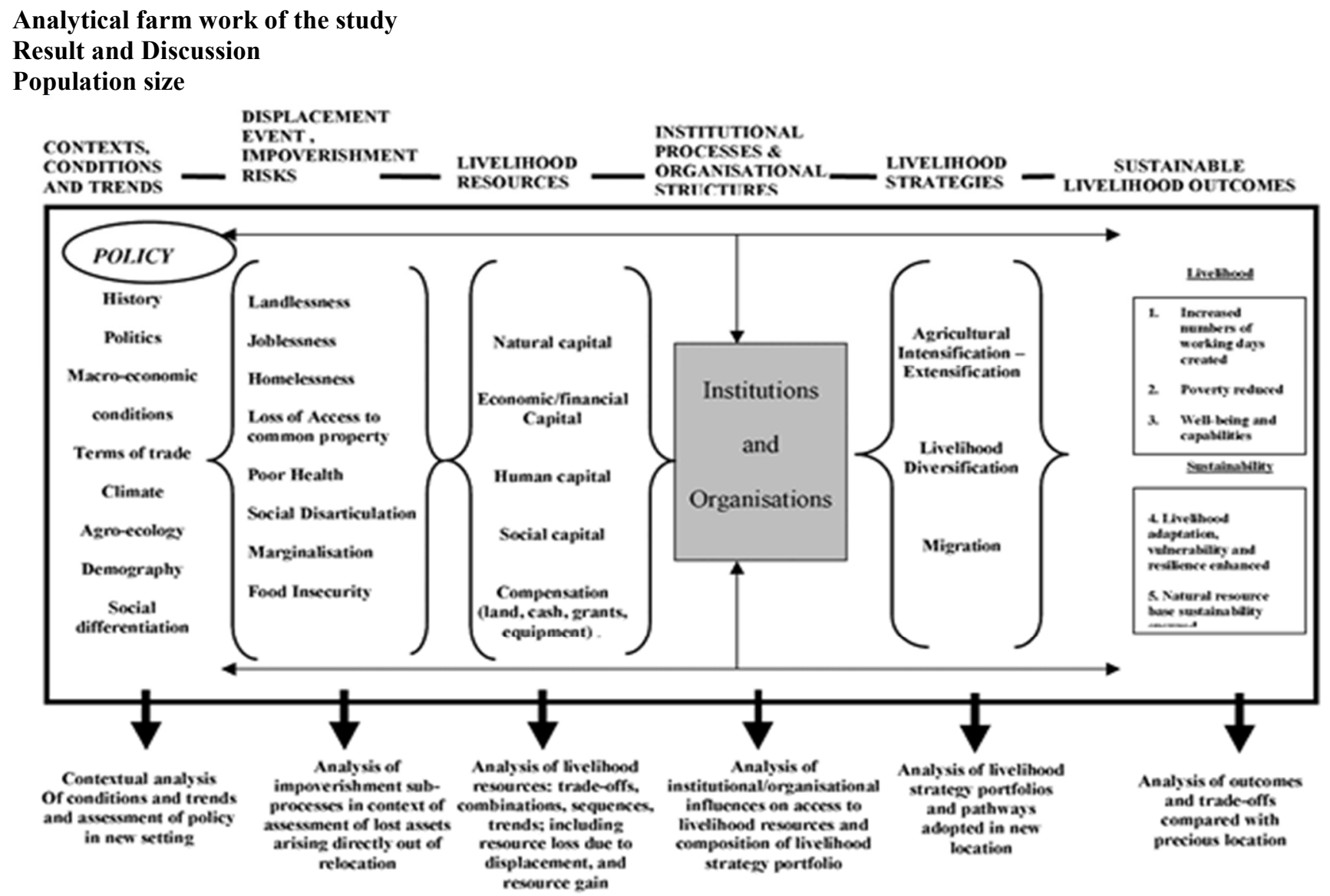

Planning and implementation of any development programs requires information on the size, structure, distribution, density, dependency ratio and demographic dynamics in general. 
Data from each project woreda finance and cooperation office annual projected total population of woredas by living areas and six disaggregation shown below in the table.

Table 1 show the total population of the proposed road project woredas

\begin{tabular}{|l|l|l|l|l|l|}
\hline Sr.no & \multirow{2}{*}{ Project Woredas } & Living areas & \multicolumn{2}{|l|}{ Total population } \\
\cline { 4 - 6 } & & & Male & Female & Total \\
\hline \multirow{3}{*}{1.} & \multirow{2}{*}{ Guna Bigimeder } & Urban & 5,600 & 3,740 & 9,340 \\
\cline { 3 - 6 } & & Rural & 54,801 & 51,772 & 106,573 \\
\cline { 3 - 6 } & & Urban+rural & 60,401 & 55,512 & 116,309 \\
\hline \multirow{2}{*}{2.} & Mektwuha & Urban & 4,272 & 4,020 & 8,292 \\
\cline { 3 - 6 } & & Rural & 37,237 & 36,171 & 73,408 \\
\cline { 3 - 6 } & & Urban+Rural & 41,509 & 40,191 & 81,700 \\
\hline
\end{tabular}

Source: each woreda finance and cooperation office 2018 annual projected population data

The above data of population imply that $8 \%$ of Guna Bigmider population and $10 \%$ of Mektewuha population live in urban area. Whereas $92 \%$ of Guna Bigmider population and $90 \%$ of Mektewuha population live in rural areas.

The implication of the data majority population of the project woredas population live in rural area where as small portion of the total population the woredas urban area.

After the proposed road project will be constructed, along the project urbanized kebles will be increase and number of urban living population increase. the probability of getting and arriving technology, social service and others developmental infrastructure will be increase as a result development come.

Total number of population along the proposed project kebles as shown the tables below.

Table 2 show the total population along project kebles

\begin{tabular}{|l|l|l|l|l|}
\hline Project Woredas & Project Kebles & \multicolumn{3}{l}{ Total population } \\
\cline { 2 - 5 } & & Male & Female & Total \\
\hline 1.Guna Bigimider & Kimirdengay & 5,600 & 3,740 & 9,340 \\
\cline { 2 - 5 } & Wukro & 3,730 & 3,256 & 6,986 \\
\cline { 2 - 5 } & Amijaya & 5,341 & 5,304 & 10,645 \\
\cline { 2 - 5 } & Atikna & 3,062 & 2,902 & 5,964 \\
\hline \multirow{5}{*}{ Mektwuha } & Giday & 3,534 & 3,323 & 6,857 \\
\cline { 2 - 5 } & Aiyada & 3,474 & 3,480 & 6,954 \\
\cline { 2 - 5 } & Zikile moka & 5,669 & 4,975 & 10,644 \\
\cline { 2 - 5 } & Aija & 4,857 & 5,911 & 10,768 \\
\cline { 2 - 5 } & Aidiya & 3,240 & 3,128 & 6,368 \\
\cline { 2 - 5 } & Aighsa & 4,272 & 4,020 & 8,292 \\
\cline { 2 - 5 } & Total project population & 42,779 & 40,039 & 82,818 \\
\hline
\end{tabular}

Source; each project woreda finance and cooperation office 2018 annual forecasting population data

Data from the each project woreda administrative office and during the field survey show that the road project directly connect Guna Bigmider with Meketwuha woredas and connect Kimirdngay_Wukiro_Amijaya_Atikna_Giday_Aiyada_Aija_Zikilmoka_Aidiya_Aighisa kebles. The total project population along the project kebles are male $=42,779$ female $=40,039$ sum $=82,818$.

\section{Social Service and Infrastructure}

One of the objectives of the road projects are the provision of access to social services. Road projects have impacts on creating access to social services of schools, health services, market places, agricultural farm inputs, and other infrastructure.

\section{Education institutions}

According to each project woreda education office the educational institutions found in the woredas and along the project kebles shown below the table.

Table 3 show numbers of schools at project woredas and along the project kebles

\begin{tabular}{|l|l|l|l|l|l|l|l|}
\hline \multirow{2}{*}{ Project woredas/kebles } & \multicolumn{9}{|c|}{ Types of school } \\
\cline { 2 - 9 } & $(1-4)$ & $(1-8)$ & $(9-10)$ & $(11-12)$ & $(9-12)$ & TVT & Sum \\
\hline Guna Bigimder & 21 & 65 & 1 & - & 1 & - & 88 \\
\hline Mektwuha & 6 & 19 & 1 & - & - & - & 26 \\
\hline Along the project kebles & 3 & 23 & 1 & - & 1 & - & 28 \\
\hline
\end{tabular}

Source: each project woreda education office

At Guna Bigimeder woreda, there are twenty one primary, sixty five primary full cycle, one secondary and one secondary and preparatory schools where as at Meketwuha woreda there are sixty primary, nineteen primary 


\section{full cycle, one secondary schools.}

Along the proposed road project kebles there are three primary, twenty three primary full cycle, one secondary and one secondary and preparatory schools.

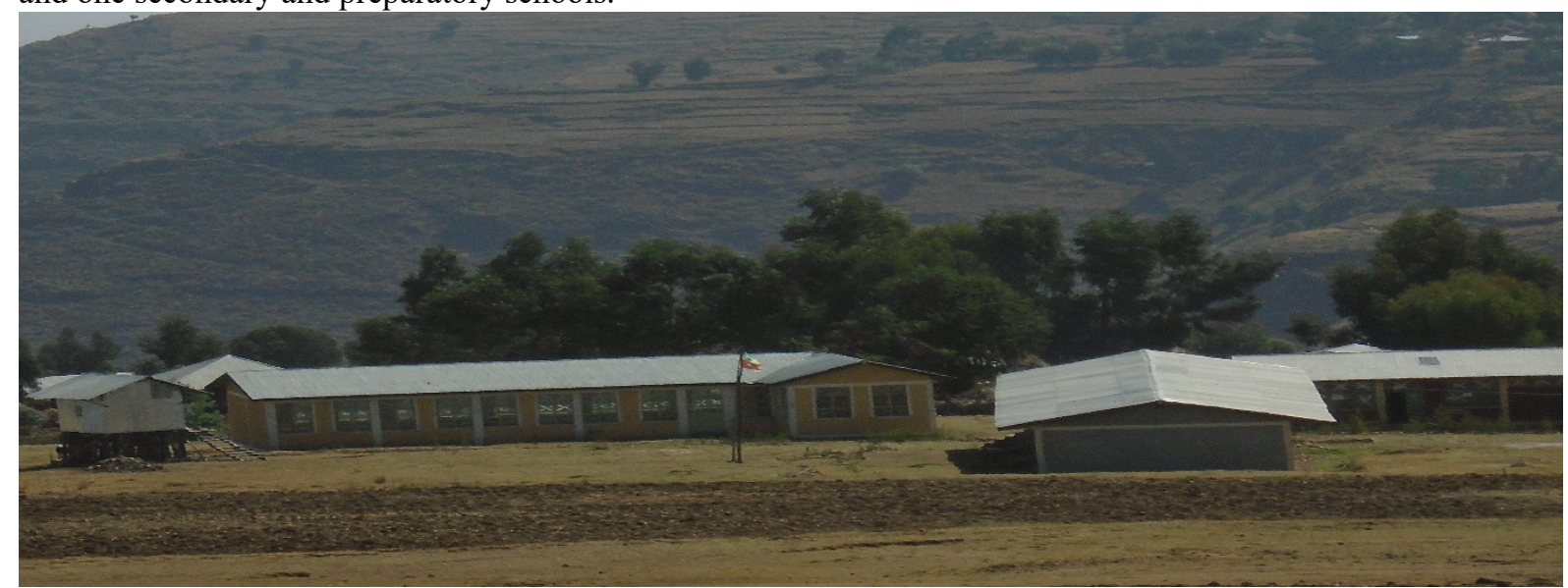

Figure 1 Aija fassildes secondary school (9-10) along the proposed project kebles

As the proposed project road will be upgrade or construct, the community along the route will be access the above educational institutions, the numbers of schools and present grade level will be increase, student dropout rate will be decline, the number of student will be increase, TVT and other private government collages will be open, UN sustainable development goal will be achieve etc.

\section{Health Institutions}

Data from Guna Bigemdar and Mektwuha woredas human health office and animal health team leader show that each project woreda and along the project kebles the number of human and animal health institutions shown below the table.

Table 4 show health institution at the project woredas and along the project kebles

\begin{tabular}{|l|l|l|l|l|l|l|l|l|}
\hline \multirow{2}{*}{$\begin{array}{l}\text { Project woredas/ along } \\
\text { project kebles }\end{array}$} & \multicolumn{4}{l}{ Human health institutions } & \multicolumn{3}{l|}{ Animal health institutions } \\
\cline { 2 - 9 } & $\begin{array}{l}\text { Health } \\
\text { post }\end{array}$ & $\begin{array}{l}\text { Health } \\
\text { center }\end{array}$ & Clinic & Hospital & Sum & Clinic & $\begin{array}{l}\text { Health } \\
\text { post }\end{array}$ & Sum \\
\hline Guna Bigemdar & 22 & 04 & - & - & 26 & - & 15 & 15 \\
\hline Mektwuha & 11 & 02 & - & - & 13 & - & 08 & 08 \\
\hline project kebles & 10 & 04 & - & - & 14 & & 09 & 09 \\
\hline
\end{tabular}

Source; each project woreda health and agriculture offices

There are twenty two human health post, four human health center and fifteen animal health post at Guna Bigimede woreda. Eleven heath post, two health center and eight animal health post at Meketwuha woreda. Along the project kebles, there are ten heath post, four health center and nine animal health post.

During public consultation the community said that due to our Keble's not connected to the keble to kebles, kebles to woreda town through all-weather reliable rural road, ambulance service not accessible as a result pregnant women born at house not in the health center, maternal and infant mortality increase, patient referral and emergency cases mortality increase.

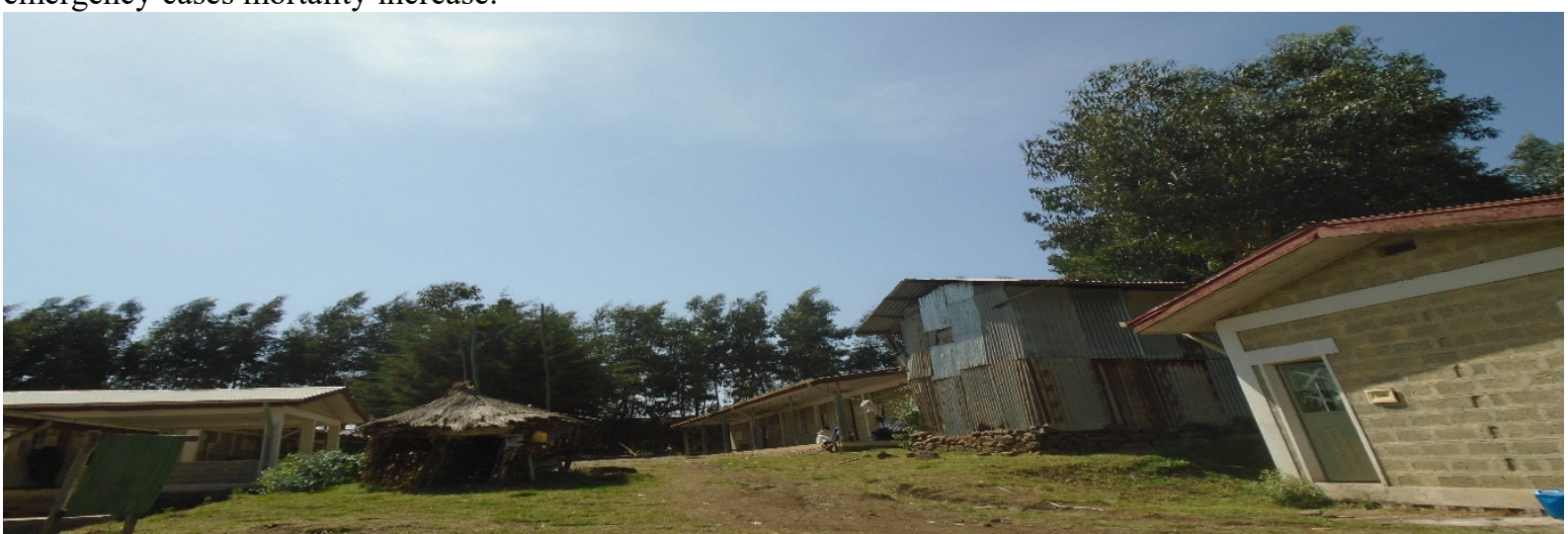

Figure 2 health center at the Aija keble along project keble

As the proposed road project will be constructed the community will better to get access health service in the above health institutions. Pregnant women follow their health and born at in the health center. Maternal and infant 
Mortality and emergency killer diseases will decline, UN sustainable development goal will be achieve.

\section{Road and communication}

Field observation show that road project has access from initial from Kimirdngay-Wukro-Amijaya-Atikna-GidayAiyada-Aija by universal rural road access program (URRAP) but after Aija-Zekelemoka-Aghisa kebles not connected. But the access were seasonal.

At the time of survey the road project has given service from Kimirdngay-Wukro-Amijaya- Atikna--GidayAiyada-Aija for motorized. But the service interrupted during rainy season.

During public discussion community said we have not get all weather reliable road service and the present access not comfortable for vehicle as a result lack of motorized plus high transportation cost leads the community living status with challenge life.

When we see the means communication at the woreda level have access wireless phone and mobile phone and along the project have access mobile telephone service but the partial network service at destination kebles

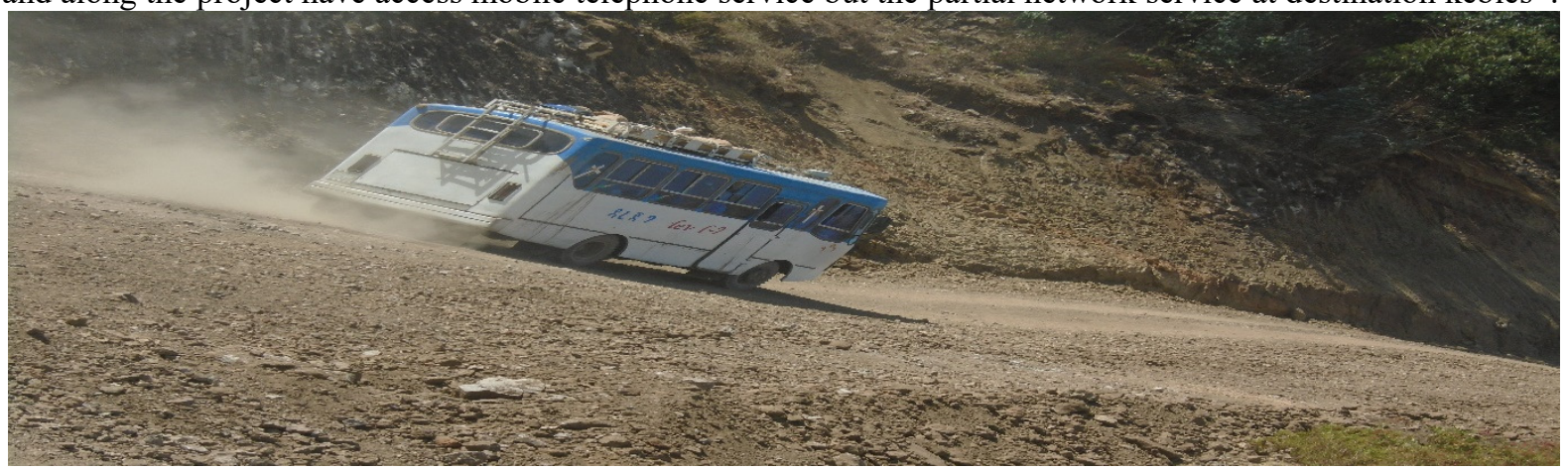

Figure 3 transport access along project kebles

As the proposed project will be upgrading and constructed the rural road problem of public transportation and transportation cost will be solved, the road coverage of the woreda and numbers of users will increase.

\section{Clean water supply}

Data from Guna Bigimeder and Mektewuha woredas water office show male $=22,704$ female $=19,687$ total 42,391 number of the population have got the clean water supply and numbers of clean water supply institutions were 455. Along the project kebles male $=10,441$, female $=8,252$ total $=18,693$ numbers of the population has got clean water supply and clean water supply institution 126. (Each woreda water office basic water supply data).

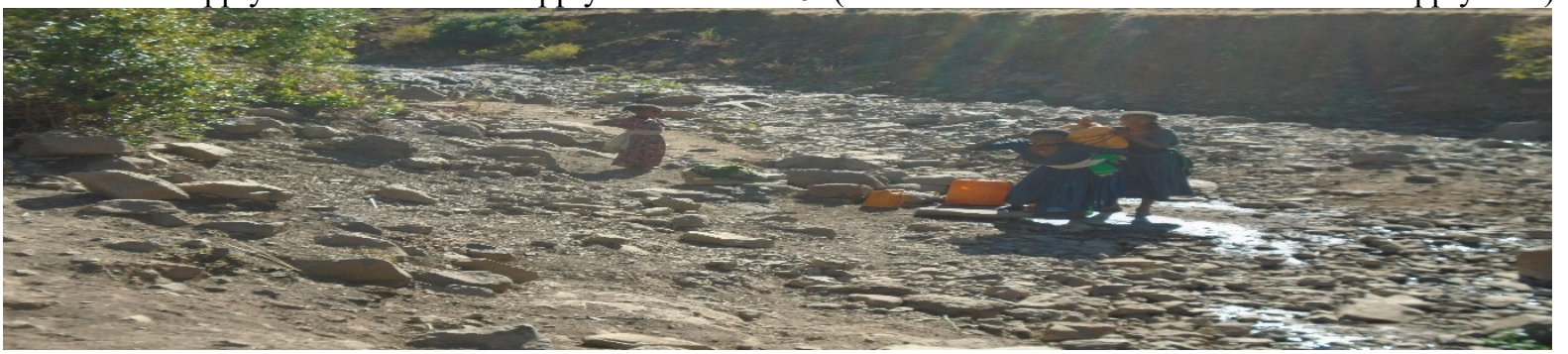

Figure 4 unprotected water supply source at the destination project

After the proposed road project constructed the probability of supply government and non-government organization clean water supply along the project community become easily as a result the numbers of population who get clean water supply will increase and the woreda clean water supply coverage increase.

\section{Hydroelectric Power Supply}

During the transect walk and data from Guna Bigmeder woreda energy supply team indicate that Kimirdingay, Wukro, Amijaya have got electric power supply. But the others kebles have not. 


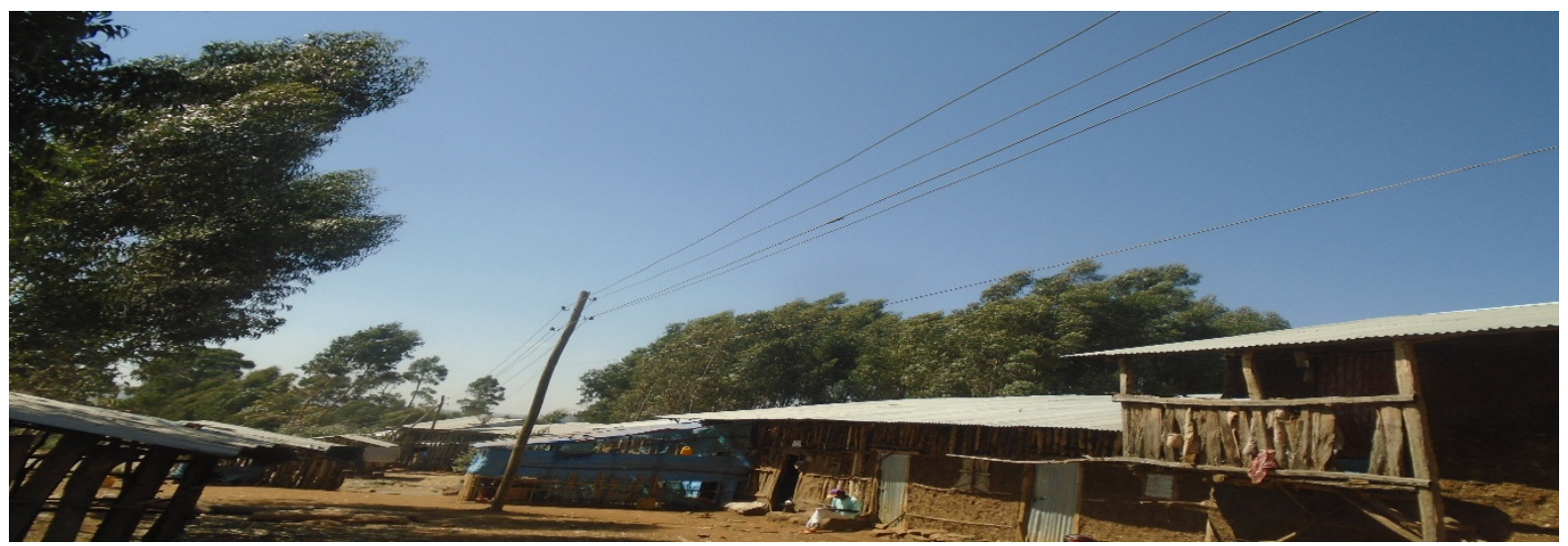

Figure 5 show hydroelectric power along the project kebles

As the proposed road project will be construct, power supplier will be easily supply power, probability of getting access hydroelectric supply will be increase, probability opening of new job opportunity will be easily and to achieve new vision of light for all.

\section{Market Center}

Market places are where goods and services exchanged. The community along the project kebles used four local market center at kimir dingay (kidam gabia), Atekna, Aija and Agihsa urban (kidam gabia).

During public discussion the community said that if the road project is constructed we easily transport our perishable agriculture product to the above market center easily and so we can get a good price for our product.

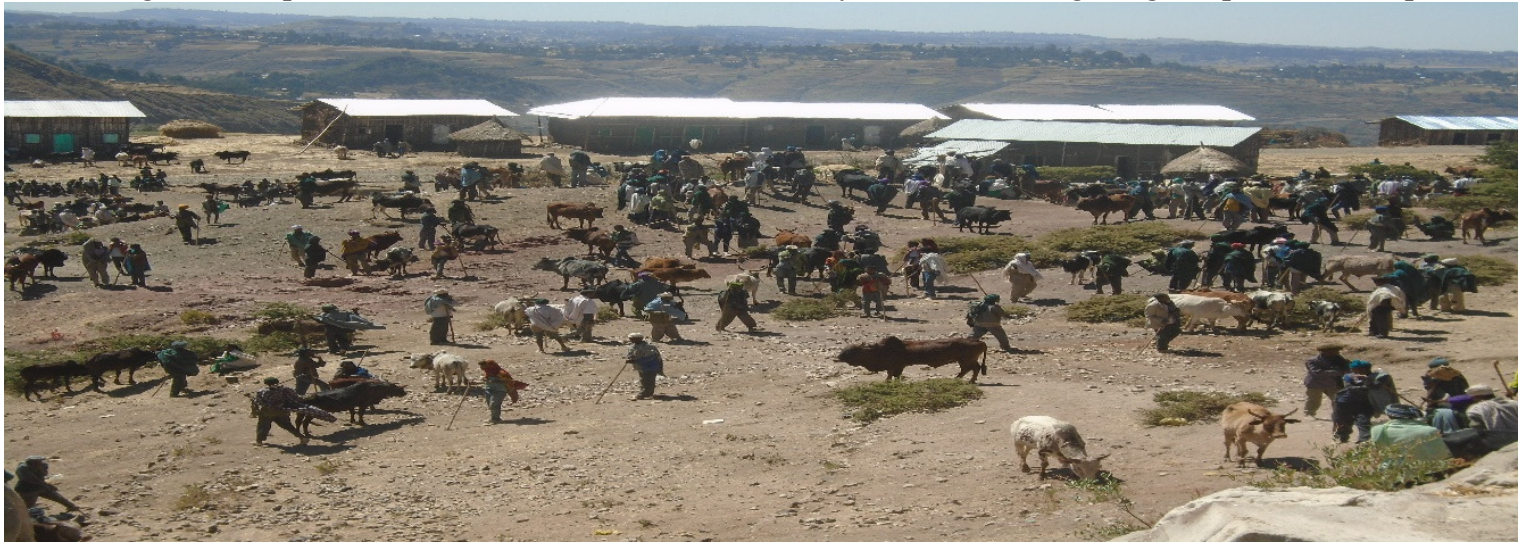

Figure 6 local Market place along the project kebles

After the construction of the proposed road project, along the project kebles exchange of goods and service will be facilitated.

\section{Financial Institution}

During the survey and data from each project woreda finance cooperation office imply that financial institution found in the woreda were Commercial bank of Ethiopia and Amhara credit and saving institution that gave credit and saving service for the woreda community. Along the project kebles Amhara credit and saving institution has opened its branch and easily access for the community to give credit and saving.

During the survey and data from Guna Bimder woreda finance cooperation office show that financial institution found in the woreda were Commercial bank of Ethiopia and Amhara credit and saving institution that gave credit and saving service for the community but in Mektwuha woreda only Amhara credit and saving institution give service. Along the alternative routes the Amhara credit and saving institution has opened its branch and easily access for the community to give credit and saving. 


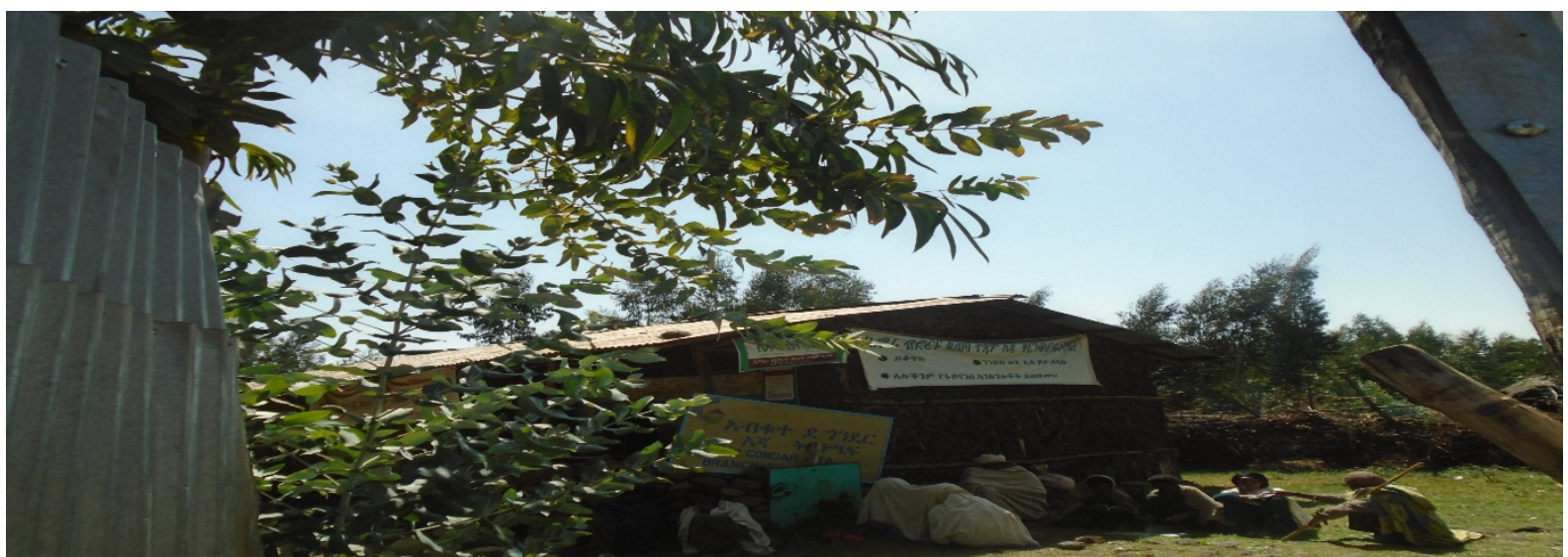

Figure 7 Amhara credit and saving finical institution along project kebles

After the construction of the proposed alternative route the probability access saving and credit money of the community along the route increase transaction of money become easily. Development come

\section{Livelihoods and Economic Activity}

Agriculture is the mainstay of the economy of region in general and that of the woreda in particular. $95 \%$ of the population livelihoods are mixed agriculture $5 \%$ of population livelihoods are non-agriculture. (woreda communication office).

During the survey and data from the each woreda agriculture office show that the major livelihoods of the woredas population were crop production and animal husbandry which means mixed economy and the same too along the project kebles.

\section{Crop Production}

Farming is the major source of income of the majority population of the project woredas in general and that of along the project kebles in particular. Crop production in the each woreda in general and along the routes in particular predominately carried out under rain-fed, with only small fragmented part being irrigated for vegetables and fruits.

Data from the Guna Bigmider woreda agriculture office show that the predominate Crops that produce with rain-fed are wheat, barely, teff, beans, peas, maize, potato and cash crop Beer barely, lentil and white onion and at Mektwuha woreda Teff, corn, sour gem, wheat, barley and cash crop lentil and small portion of sesame in the woredas and the along the road project kebles predominate crops are wheat, barely, teff, bean, peas and cash crop beer barely, lentil and white onion etc

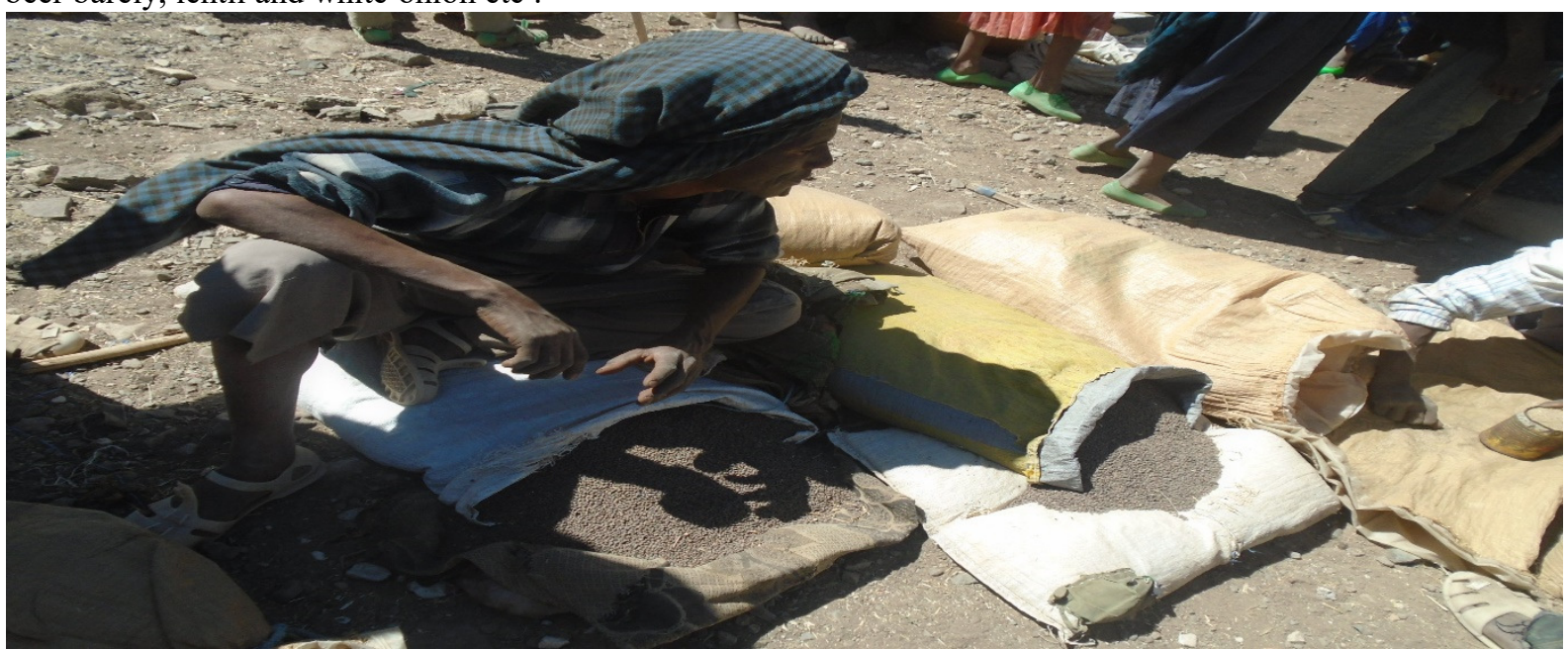

Figure 8 show lentil product along the project keble market place

Along the proposed road project the farmers said that we irrigated fruits and vegetables but lack of access road our irrigable product cannot get sufficient market and we cannot get agricultural input such as fertilizers and selected seeds at the peak time of agriculture period.

Then after the proposed road project will be constructed our rain-fed and irrigated agriculture product easily get access market, access agricultural input, access improved seed and technology that improve crop production and productivity and amount of irrigable land and river increase. 


\section{Livestock Husbandry}

Animal husbandry is the second source of income of the woredas population in general and along the project kebles in particular.

According to data from the each project woreda livestock resource office the total numbers of livestock population in the woredas are as follow.

Table 5 show cattle population in the project woredas and along the project kebles.

\begin{tabular}{|l|l|l|l|l|}
\hline \multirow{2}{*}{ Sr.no } & Type of cattle & project woredas & \multirow{2}{*}{} \\
\cline { 3 - 4 } & & Guna Bigimeder & Mektwuha & Project kebles \\
\hline 1 & Dewlap & 36,780 & 46,792 & 37,890 \\
\hline 2 & Mane & 23,456 & 11,648 & 11,547 \\
\hline 3 & Sheep & 36,578 & 32,439 & 12,567 \\
\hline 4 & Goat & 34,568 & 54,065 & 25,647 \\
\hline & Total & 131,382 & 144,944 & 87,651 \\
\hline
\end{tabular}

Source: each project woreda livestock resource offices

As the proposed project will be constructed, the community along the road project will be benefit by using improved livestock genetics, access market for animal and animal product.

\section{Small and Microenterprise}

In Ethiopia, a study undertaken by the Central Statistical Agency (CSA) disclosed that there were about 974,679 micro enterprises, generating a means of livelihood for about 1.3 million people (CSA, 2002). Another study conducted in 2003 by CSA also revealed that 1,863 SMEs had created employment opportunities for about 97,782 citizens (CSA, 2003).

Data from the each woreda small and microenterprise show that the enterprises found at woredas are service, manufacturing, sub agriculture, construction and trade. Total employment opportunity created by those enterprises are as follow.

Table 6 show employment opportunity in the projected woredas

\begin{tabular}{|l|l|l|l|}
\hline \multirow{2}{*}{ Type of service } & \multicolumn{2}{|c|}{ Number Employer } & Total \\
\cline { 2 - 4 } & Male & Female & 31 \\
\hline Service & 8 & 23 & 21 \\
\hline Manufacturing & 13 & 8 & 38 \\
\hline Sub-agriculture & 34 & 4 & 76 \\
\hline Trade & 58 & 18 & 85 \\
\hline Construction & 67 & 18 & \multicolumn{2}{|l}{} \\
\hline
\end{tabular}

Source; each project woreda small and microenterprise

As the proposed route will be constructed temporary, daily and permanent employment will be created for the local community even capital will create for the local community.

\section{The importance of Proposed Road project given by Local Consultation Process}

Woreda rural road steering committee lead by the woreda administrator, key persons, elderly, representative of youth and women, religion leaders and some of the community were consulted. The main objective of the consultation was to create awareness about the proposed road project among the community and stakeholders, to obtain background information relevant to socio-economic impacts and to understand the attitude of the local community towards the proposed project. The public consultation was carried out at Woreda and kebeles level at different times, and place mostly with group meeting formally, steering committee and to some extent with key persons.

Since, the road project has local, regional as well as national significance we accord it top priority. We, as members of the leadership and local residents, are committed to ensure the smooth operation and implementation of the Project road. We are also aware of the adverse impacts of the project on some peoples' livelihoods. We understand that PAPs will be compensated fairly for their lost assets and resettlement and rehabilitation efforts will be launched to restore their incomes and livelihoods. Further, we are also committed to addressing complaints that may be lodged from PAPs and the public at large during construction period.

Although the discussion was held in Woreda steering committee and most of Keble communities, very similar opinions were expressed with regard to the points of discussion recorded above. In general the project area communities have a very positive attitude towards the proposed project since the seasonal service existing road infrastructure has an influence on their socio-economic life.

In general the each project woreda cabinet and Community consultation at each woreda, kebles level the proposed project have the following benefit. Availability of all-weather reliable roads, Improve access to social infrastructures service, increased access to market places for local produces, reduced transportation costs, access 
to new employment centers, facilitate credit and saving access, to supply industrial product for the local consumption, solve the problem of clean water supply, encourage urbanization ,strengthen of local economy, strengthen farmers' co-operative organization, improve access to farmers extension service, encourage irrigation co-operative, to solve question of good governance

Negative side of the project are;

-affect farm land, homesteads, houses, and perianal crop during construction and after construction, car accident, air pollution, erosion of farm land listed during the community meeting.

Some of the possible measurement listed during consultation are

- If farmer's large size of farm land will have taken during the construction the road project, the keble community take compensation either in kind or in birr. Common land have given to the affected farmers.

- If the poor segment of the community houses affected during the construction of the road project, the community said we will construct their houses

During the proposed road construction the road side should have a water way otherwise our marginal farm land erode during rainy season.

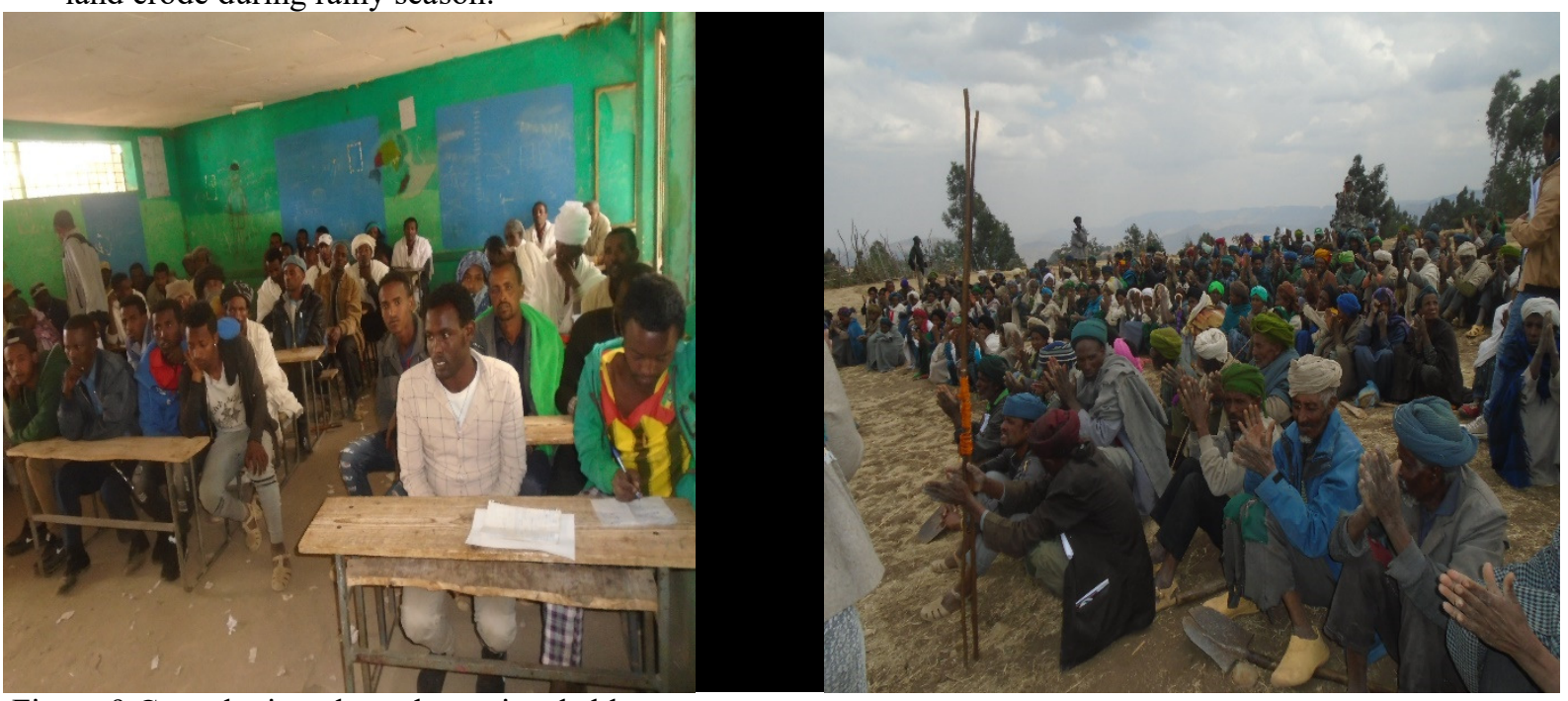

Figure 9 Consultation along the project kebles

\section{Adverse socioeconomic impact}

There are a number of negative impacts that influence the construction of the road project, and some of the negative impacts could be avoided if proper mitigation measures are carried out. The negative impacts are related to expropriation of farm land, crop loss, houses loss, spread of malaria, STD and HIV/AIDS, growth of squatters and uncontrolled settlements, noise disturbance, spoil dumping and pressure on local services and facilities, and impact on settlements.

\section{Impacts on urban and rural houses}

In road and other infrastructure projects, impact on houses that are either used for residential or business purposes due to the widening of existing right of ways (ROW) or construction of new road is a common phenomenon. In the project road, 78 structures which include huts/houses/buildings will be fully affected by the project construction. Number of project affected households due to loss of residence and business houses are about 15 of $\mathrm{which}$ male=10, female $=5$ which will be dislocated as the result the impact. The affected houses are mainly of constructed with concrete, wood, stone and mud and having either grass or corrugated iron sheet roofing.

Most of the affected houses are located in Kimirdingay, Wukro keble centers, Amijya keble center, Aribigbaya, Megnagna, Aija and Aghisa urban and rural villages. (Field survey) 


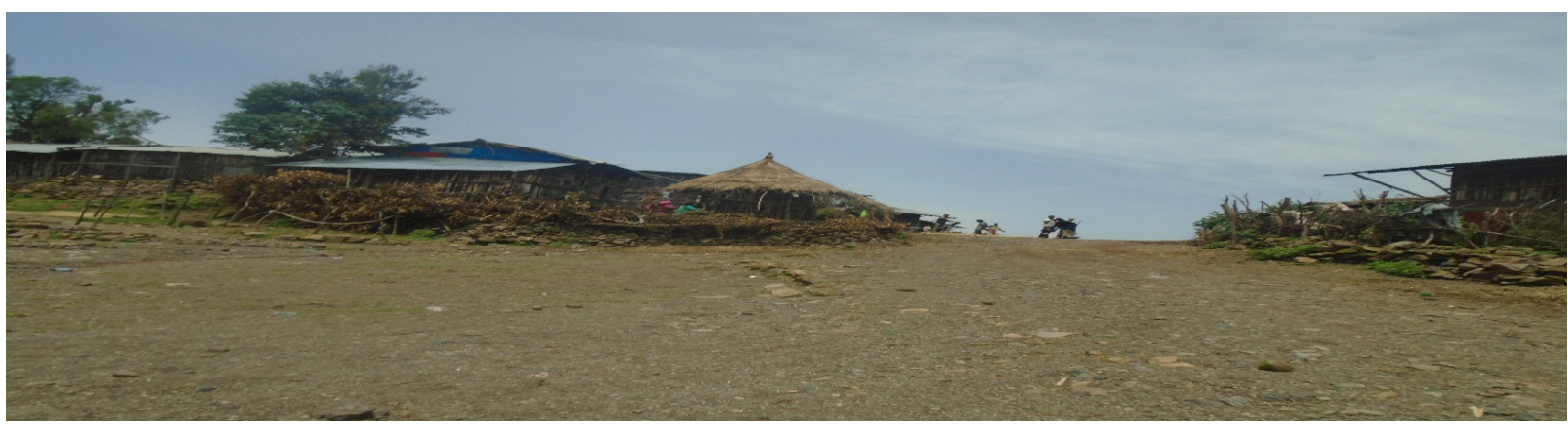

Figure 10 effect on houses at Aribigabiya villages

\section{Growth of Squatters and Uncontrolled Settlements}

Construction of roads in most cases attracts the local population to construct houses very close to road sides due to a number of reasons. Some construct houses to become eligible for compensation payment and some others construct due to the induced development opportunity by the road construction. In some cases, these squatters and uncontrolled settlements affect the development of local area to both for residential purposes.

\section{Exposure to HIV / AIDS and other Sexually Transmitted Diseases (STD)}

In Ethiopia, the HIV/AIDS pandemic, in recent years, has emerged as a major health hazard, affecting mainly the age group of 15 to 49 years. HIV / AIDS emerged as a major health hazard in recent years in Ethiopia. Road construction and other similar type of project workers, and truck drivers are considered as having high potential (or good vectors) for the spread of Sexually Transmitted Diseases (STDs) and HIV/AIDS virus due to their mobility. This is partly because construction workers are mostly young and sexually active group of the population and are mobile, and are also forced to live in working camps.

Contacts and communications created between local communities and construction workers who have come to the project area from different localities and mainly from major towns will expose the local community to new and alien cultures and behaviors that might be against local cultures and behaviors.

The introduction of new and alien cultures and behaviors may contribute to the spread of communicable diseases such STD and HIV/AIDS. Similarly, other unwanted experiences such as, the coming of sex workers to the project area from major towns and cities will contribute to the increase in the number of sex workers, alcoholism and crime.

\section{Impacts of the project on farmlands}

The construction of new road project mainly demand new farm, grazing, brush and forest areas and hence, there will be much farmland that will be lost permanently. There will be also temporary lose farmland by households. The Kimirdingay-Atekna-Aghisa road project demand few new lands at Zeklimoka, Ayida and Aghisa kebles and also demand new grazing land at the same kebles/villages. And also demand new land during widening and alignment change of the existing road along the route. About 234 strip of farm land will be affected, and consequently about total project affected households are 135 male $=123$, female $=12$ household heads will lose strip of farmland. However, no single farming household will fully lose his/her farmland. (Field survey). An estimation of 6.84 hectare of farm land will be affected due to road project

\section{Impacts of the Project on Social Services}

Disruptions of social services and amenities due to the project are virtually existent since there may exist along the route. Social service that affected by this road projects are school fence, church fence and electric pole since they exist along the proposed project right of ways

On the other hand, the proposed project will have a great impetus on the development of these services and others like postal, internet and public transport.

The impact on social services such as health centers exist at Amijaya keble center urban.

\section{Impact on perennial crops and Trees}

Field observation coupled with survey data show that the proposed road project has an impact on trees. Since they existed with in the project right of ways. As field observation and survey report show that 56 large size 125 medium and 210 small size eucalyptus trees will be affected by the project.

\section{Impacts associated with ancillary works}

Ancillary works associated with the road construction like quarry and borrow pits, construction camps and detour roads will dispossess certain grazing lands and trees. Normally such demands are temporary in nature and the land 
shall be reinstated to its original condition. However, past experience shows there is a negligence to reinstate these lands by the contractors. Moreover, camp sites as they remained for other services after the end of the project shall not be constructed on rich agricultural lands and ecologically sensitive areas. This RAP assumes the land required for temporary activities related to the road construction reinstated to their pre-project situation.

\section{Possible Mitigation measure for adverse impact}

- Compensate for lost houses (residential and commercial) as per the law

- Provide land for the affected households so that they could construct houses

- Involve PAPs in the property valuation committee

- Give priority in the employment of casual workers for household members of PAPs that have lost their house for the road construction works.

- Woreda and Kebele authorities monitor that local population do not construct any permanent or temporary structure close to the ROW after the cutoff date

- Provide squatters with rehabilitation measures (creating employment opportunities for loss income, etc)

- Compensation payment for lost assets and properties as per the law.

- As a preventive measure, construction workers and local population must be informed through awareness raising and education campaigns about HIV / AIDS. This has to be done on the one hand by the contractor, responsible for workers and on the other hand by the communities, along the project road, targeting especially women. At the community level, special information campaigns for women should be enhanced.

- Condoms can be provided at subsidized rates or for free and health facilities must be supported with supply of condoms and must communicate information about risks. To have an effect in the longer term, schools should include information campaigns and/or special courses, as suggested below.

- Conduct education and awareness creation campaigns on the spread and transmission of STDs and HIV/AIDS for construction workers and local communities living close to the construction camp sites.

- Provide free distribution and provision of condoms to construction workers by the

- Put educational posters and flyers on HIV/AIDS, using local languages at public gathering locations, bus terminals, schools and by road sides to minimize the spread of HIV/AIDS.

- Adopt FDRE and ERA's Policy on HIV/AIDs, and provide special care and support to HIV/AIDs positive staff and AIDs patients.

- Spread education for preventing communicable diseases, STD and HIV/AIDS and for practicing "safe sex" by using condom.

- Monitor the above mitigation measures through proper monitoring indicator

- The affected households will be compensated as per the law for lost crop and will be allocated similar plot of land if there is land available in the area otherwise prepare farm land compensation .

- Give priority in the employment of casual workers for household members of PAPs that have lost their land for the road construction works.

- Compensate farmers for loss of crops (perennial or annual), trees as per the Federal legislation (Proclamation 455/2005) based on market prices.

- Consult and involve PAPs in the estimation of costs for lost assets.

- Allow enough time for project affected persons (PAPs) to remove their crops (perennial or annual) and trees.

- Give priority in the employment of casual workers for household members of PAPs that have lost their land for the road construction works.

- For land being used as detour or for other construction related purposes and also for loss of its fertility.

- Avoid creating associated with ancillary works on farm and grazing land or near farms.

- On the completion of the work clean properly and restore the temporarily occupied land.

\section{Conclusion}

Kimerdingay_Atekena_Meketwuha road project will have positive and negative /adverse socioeconomic impact. The overall positive socioeconomic impacts of the proposed road project include availability of all-weather reliable roads, reduced transportation costs, increased access to market places for local produces, access to new employment centers, better access to social service centers like health institutions, and strengthening of local economy are felt during the operation phases of the project road.

The adverse impact of the proposed road project include increased traffic accidents, pollution due to increased vehicle exhaust gases and transportation of hazardous material in transit, noise and road side litter, displacement of people, damages to properties and crops, interruption of social services like water supply, electricity and telecommunication services, expansion of HIV/AIDS and other STDs, drug abuse, commercial sex work, child 
labor, theft, exhaustion of natural resources, price escalation at local level etc.

During the construction and after the project proper mitigation measure should be taken to minimize or eliminate the adverse impact of the project which have taken in the mitigation measure above the paper.

\section{Recommendation}

The regional government should construct the proposed road project since it facilitate the socioeconomic transformation of project communities.

\section{Reference}

A proclamation to provide for the expropriation of landholdings for public purposes and payment of compensation; proclamation No.455/2005

Constitution of the Federal Democratic Republic of Ethiopia Proclamation No.1/1995.

Council of Ministers Regulations No. 135./2007 council of ministers regulations on the payment of compensation for property situated on landholdings expropriated for public purpose.

Detailed Engineering Design and tender document preparation for DERA -MECHARA road upgrading project. Environmental Impact Assessment, Wilbur Smith Associates in Association with Pan African Consultants, July 1998, Addis Ababa, Ethiopia.

Ethiopian Roads Authority, Environmental Procedures Manuals, 2001, Addis Ababa, Ethiopia.

Ethiopian Roads Authority, Resettlement/Rehabilitation Policy Framework, February 2002, Addis Ababa, Ethiopia.

Feasibility and EIA study, detailed engineering design and tender document preparation of Jima - Chida road project; final revised resettlement action plan (RAP) October, 2016.

Feasibility Study of RSDP II: Seven Roads Projects: Final Study Report, Volume 1, 1999, Kocks Consult GMBH Consulting Engineers in association with Metaferia Consulting Engineers, Addis Ababa, Ethiopia.

Kimirdingay_Atekena_Meketwuha road project route selection detail engineering design document February, 2018

Road Sector Development Program Support Project (February 2007); Resettlement /réhabilitation Policy Framework.

Road Sector Development Programme 1997-2007. Second Draft Final Report. Ethiopian Roads Authority, Addis Ababa, January 1996. 